\title{
Revascularization by Using Sequential Composite Graft of a Patient Suffering from Traffic Accident with Lower Extremity Circulation Disorder: A Case Report
}

\author{
Trafik Kazası Yaralanmasına Bağlı Alt Ekstremite Dolaşım Bozukluğu Olan Hastanın Sıralı \\ Kompozit Greft Kullanılarak Revaskülarizasyonu: Olgu Sunumu
}

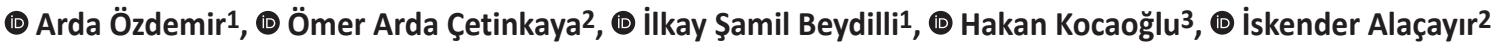 \\ ${ }^{1}$ Ankara University Faculty of Medicine, Department of Plastic, Reconstructive and Aesthetic Surgery, Ankara, Turkey \\ ${ }^{2}$ Ankara University Faculty of Medicine, Department of General Surgery, Division of Peripheral Vascular Surgery, Ankara, Turkey \\ ${ }^{3}$ Ankara University Faculty of Medicine, Department of Orthopedics and Traumatology, Ankara, Turkey
}

\section{Abstract}

Traffic accidents are the most common cause of the lower extremity injury among the young adults. Circulatory problems due to vascular injury, such as total or partial rupture of venous and arterial system are the significant cause of the morbidity related to this kind of trauma. In these cases, revascularization should be the first option to rescue the extremity unless the patient is stable; otherwise, amputation can be performed. Here we reported a patient with multifragment fracture of femur, wide destruction of the soft tissue and popliteal artery injury of the left lower extremity due to the traffic accident, who was treated with late synchronous revascularization with composite graft and saphenous vein.

Key Words: Lower Extremity, Revascularization, Amputation, Vascular Graft

\section{$\ddot{0} z$}

Trafik kazaları, genç yetişkinler arasında alt ekstremite yaralanmasının en yaygın nedenidir. Venöz ve arteriyel sistemin tamamen veya kısmi ruptürü gibi vasküler yaralanmaya bağlı dolaşım sorunları, bu tür travmalara bağlı morbiditenin önemli nedenidir. Bu durumlarda ve hasta stabil olduğu sürece, revaskülarizasyon ekstremiteyi kurtarmak için ilk seçenek olmalıdır; aksi takdirde ise ampütasyon yapılabilir. Bu olgu sunumunda, kompozit greft ve safen ven ile geç senkron revaskülarizasyon ile tedavi edilen, çok parçalı femur kırığı, sol alt ekstremite yumuşak dokuda geniş harabiyet ve popliteal arter yaralanması olan bir hasta bildirilmiştir.

Anahtar Kelimeler: Alt Ekstremite, Revaskülarizasyon, Ampütasyon, Vasküler Greft

\section{Introduction}

According to the National Trauma Data Bank of the United States of America, a total of 278,000 cases of lower extremity damage had been occurred and led to 3,700 traumatic amputations during 2012 (1). Blunt trauma, such as traffic accidents that affect the people's exterior of the vehicle, is a serious cause of morbidity, which mainly affects the young male population that can result in extremity amputation. The popliteal area is commonly injured in traffic accidents. The popliteal artery is the second most common vessel damaged in the lower extremity and responsible for poor prognosis due to ischemia $(2,3)$. This paper aims to highlight that the prior treatment should be revascularization or reconstruction rather than amputation in a young patient to reduce the cost by the comorbidities of limb amputation (4).

Address for Correspondence/ Yazışma Adresi: Arda Özdemir,

Ankara University Faculty of Medicine, Department of Plastic, Reconstructive and Aesthetic Surgery, Ankara, Turkey

Phone: +90 5559768100 E-mail: arda.ozd@ @otmail.com ORCID ID: orcid.org/0000-0002-9959-7315

Received/Geliş Tarihi: 01.01.2021 Accepted/Kabul Tarihi: 11.06.2021

๑Telif Hakkı 2021 Ankara Üniversitesi Tıp Fakültesi

Ankara Üniversitesi Tıp Fakültesi Mecmuası, Galenos Yayınevi tarafından yayınlanmıştır.

Yayınlanan tüm içerik CC BY-NC-ND lisansı altındadır. 


\section{Case Report}

A 44-year-old male without a history of any chronic disease or medication, who had fragmented femoral bone fracture and tissue defect that included the superior and inferior parts of the patella that approximately sized $15 \mathrm{~cm}$ in length and $3 \mathrm{~cm}$ in width covered with partially necrosed skin according to a traffic accident admitted to our department.

After his first hospitalization, the patient underwent external fixation for the fragmented femoral bone fracture and bypass from the superficial femoral artery to the popliteal artery using below the knee saphenous vein graft taken from the right leg for popliteal artery injury. The tissue defects of the suprapatellar and infrapatellar regions of the left leg were treated by splitthickness skin grafts taken from the right leg.

The patient was admitted to Ankara University Medical Faculty General Surgery Intensive Care Unit with an external fixator, non-patent femoropopliteal by-pass graft and infected soft tissue areas of the left leg. The first physical examination of the patient revealed external fixation that extends above the knee, an incision scar in the left femoral area, and a wide soft tissue lesion that was clinically infected in the left popliteal region and the middle section of the tibia. No distal pulses were detected in the palpation except the left femoral artery pulse. The left foot was pale and cold compared to the right foot. In the neurological examination of the patient, there was a foot drop appearance on the left side. The patient's ankle/arm index (ABI) was 0.55 .

The digital subtraction angiography (DSA) performed on the patient revealed complete occlusion at the $1 / 3$ distal part of the left superficial femoral artery and re-filling of the popliteal artery with the collateral flow $2 \mathrm{~cm}$ above the knee joint.

Because of the lack of critical leg ischemia, elective revascularization was considered in this period. For the purpose of infection eradication, debridement was performed before the vascular intervention. Antibiotherapy of the patient was initiated with intravenous colistin and meropenem. Daily washing with physiological saline and the wet dressing was applied to the areas with tissue defects. Negative pressure wound therapy (intermittant, $125 \mathrm{mmHg}$ pressure and silver foam) was applied to the patient in the ongoing process for approximately 2 weeks. After the patient had ischemia and resting pain on the $5^{\text {th }}$ finger during his treatment, the patient immediately underwent femorodistal bypass surgery, despite a non-eradicated but clinically controlled infection. The patient's $A B I$ was 0.32 just prior to the surgery. No other interventions such as Doppler ultrasonography were obtained.

From the femoral artery to the suprapatellar region, an $80 \mathrm{~cm}$ in length and $6 \mathrm{~mm}$ in width polytetrafluoroethylene vascular

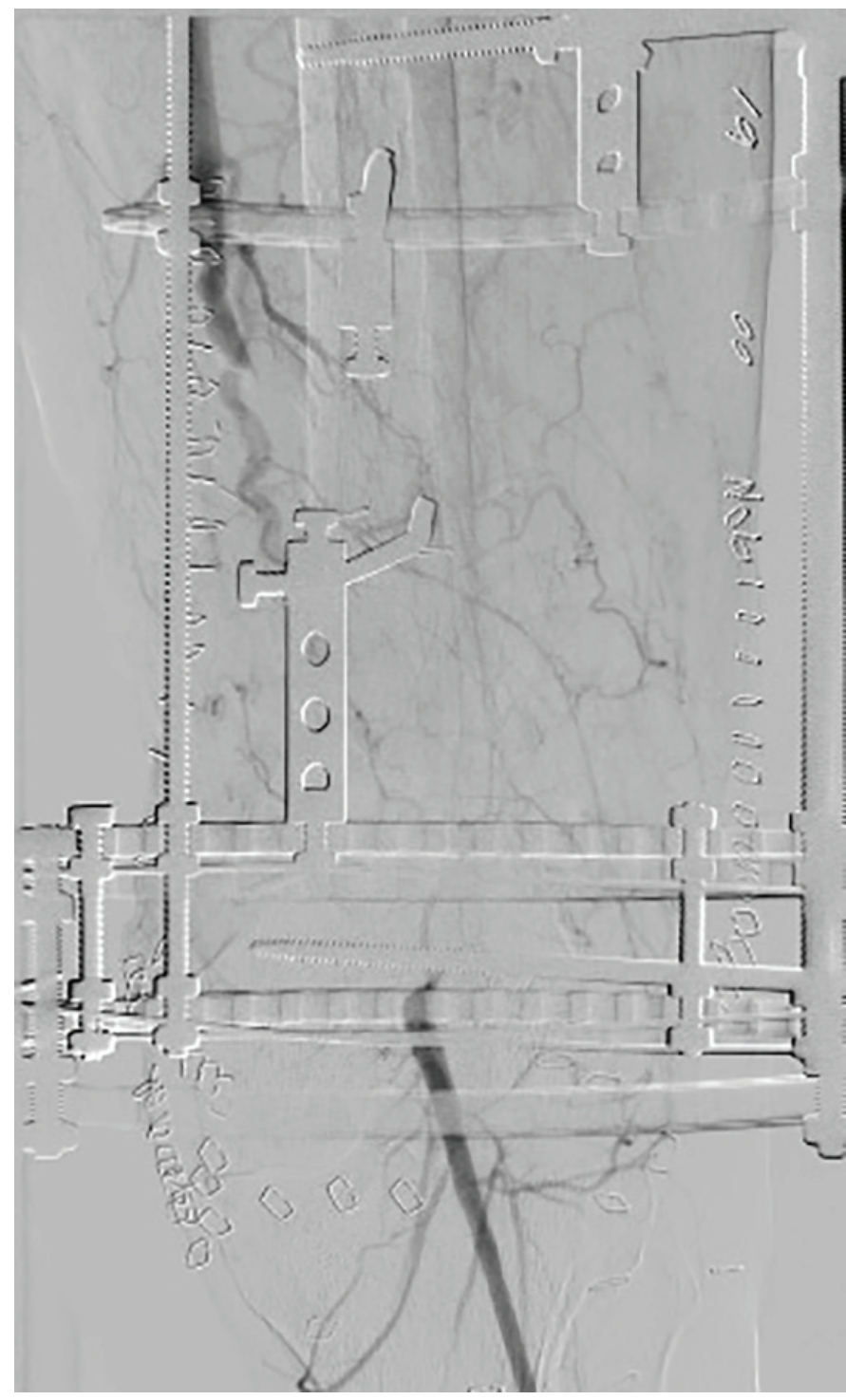

Figure 1: Exploration of the posterior tibial artery

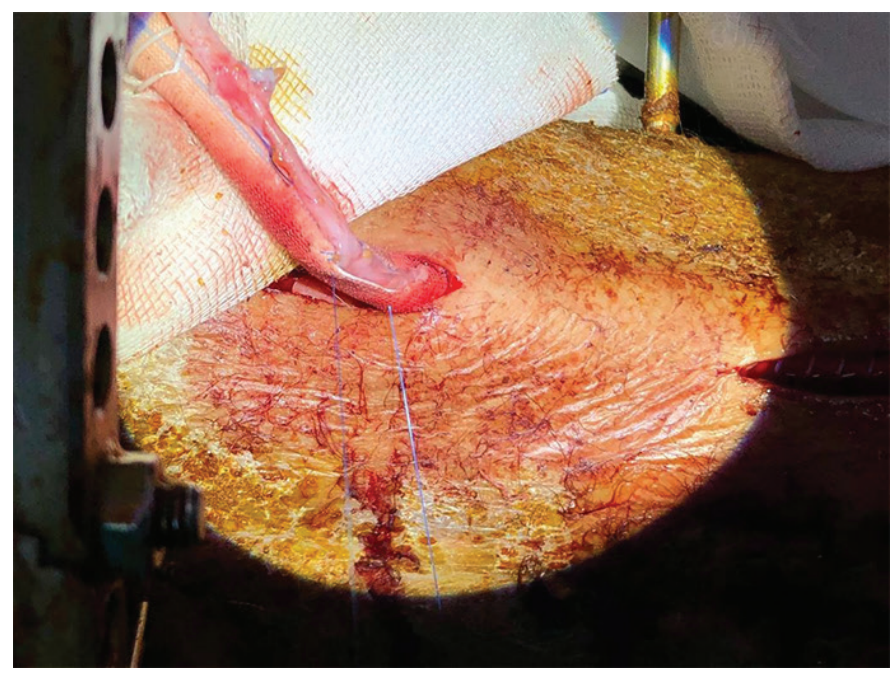

Figure 2: The anastomosis of the femoral artery and the synthetic graft at the proximal region 
graft (Maquet ${ }^{\mathrm{TM}} 45$ Barbour Pond Drive, Wayne, NJ) which was extranatomically located and was anastomosed to the reverse saphenous vein graft that was taken from the right leg. The exploration of the posterior tibial artery is shown in Figure 1.

The reverse saphenous vein graft was proximally anastomosed to the vascular graft and distally anastomosed to the posterior tibial artery in the middle tibial region after artificially conducted through the interosseous membrane. The anastomosis of the femoral artery and the synthetic graft at the proximal region is shown in Figure 2.

The pathway of anastomosis between the synthetic graft and the saphenous vein at the suprapatellar region is shown in Figure 3.

The proximal anastomosis was performed with 5-0 polypropylene and the distal anastomosis was performed with 6-0 polypropylene suture material. The anastomosis of the synthetic graft and the saphenous vein at the suprapatellar region is shown in Figure 4 and the preparation of the posterior tibial artery before the anastomosis to the reverse saphenous vein graft is shown in Figure 5.

In the postoperative period, the $A B I$ value was 0.90 . Leftsided tibialis posterior and dorsalis pedis pulses were palpated.

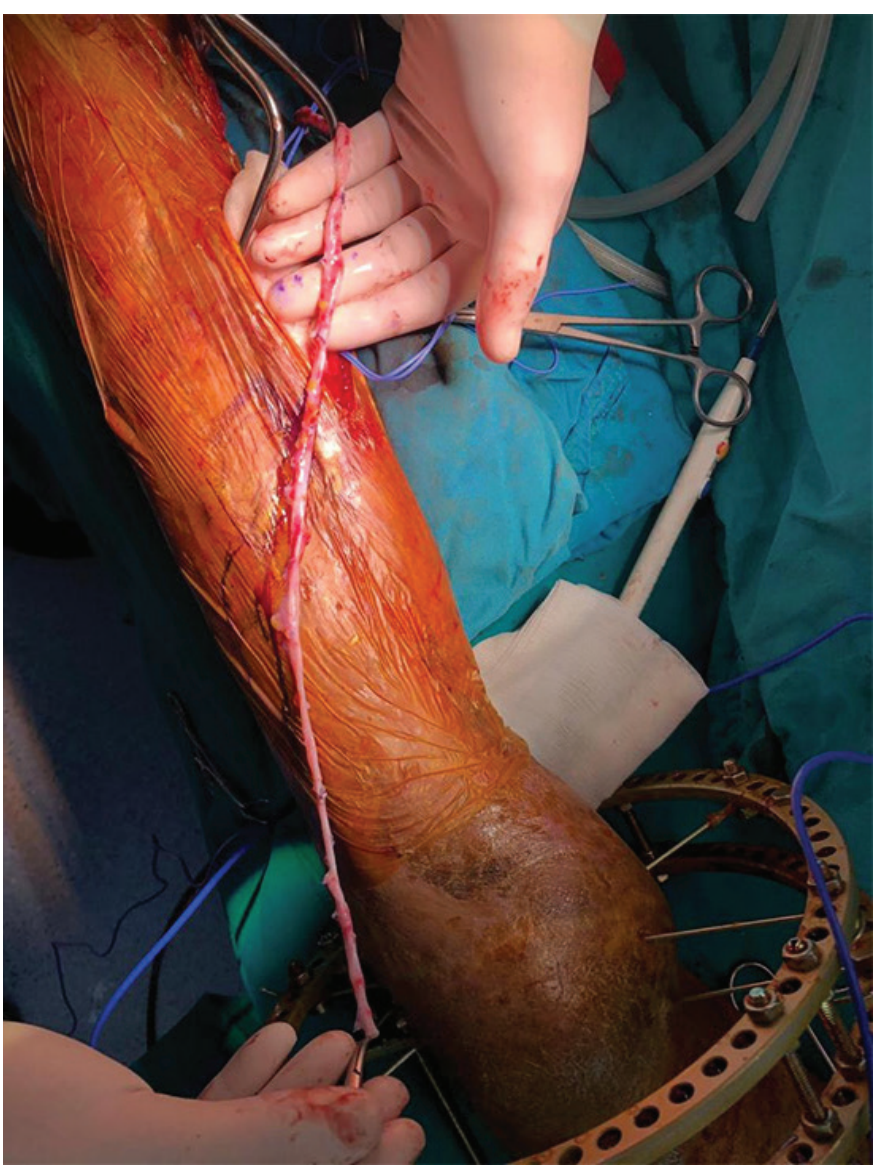

Figure 3: The pathway of anastomosis between the synthetic graft and the saphenous vein at the suprapatellar region
For the infection eradication of the patient, 3 weeks of intravenous antibiotherapy (piperacillin/tazobactam, 3x4.5 gr) based on repeated wound and tissue culture results was given. Also wound debridement was executed.

\section{Discussion}

The extremity sparing revascularization of the limb after high-energy trauma such as outer-vehicle traffic accidents is a challenging process. When performing revascularization in these patients, it is preferable to use autogenous tissues, such as the patient's own saphenous vein. Since the patency of the anastomosis is correlated with the use of autogenous tissue, a sequential composite graft should not be used if possible (5). The usage of the syntetic graft was referred for the patient who is presented in this case report because of the insufficient length of the saphenous vein for by-pass of the femoral artery and the posterior tibial artery.

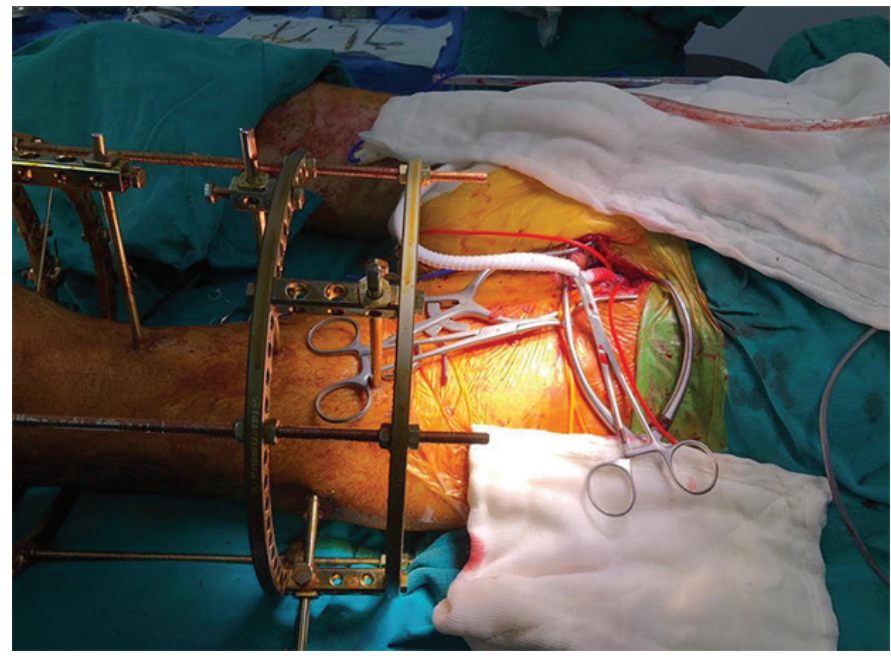

Figure 4: The anastomosis of the synthetic graft and the saphenous vein at the suprapatellar region

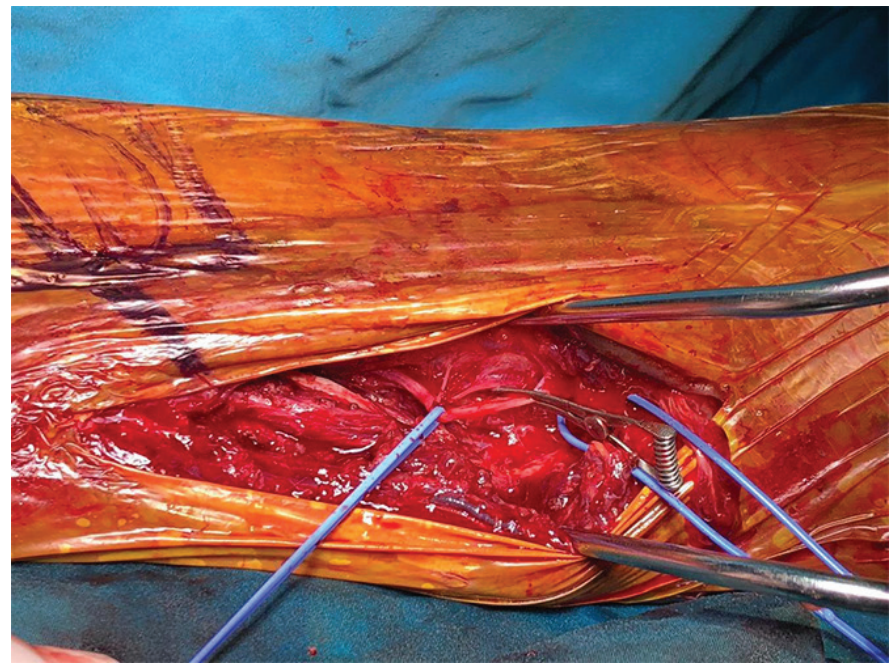

Figure 5: The preparation of the posterior tibial artery before the anastomosis to the reverse saphenous vein graft 
Although the patency ratios are lower in composite sequential revascularization using autogenous tissue and synthetic graft together, composite sequential revascularization had to be applied to the patient in our case due to the lack of adequate autogenous tissue. However, the patient in our case had a higher chance of patency due to the fact that the patient was young and the distal vessels were more healthy due to the lack of additional diseases which may cause endothelial damage such as atheroclerosis and diabetes. While using the sequential composite graft, it was aimed to increase the blood flow to the distal tissues by using the synthetic graft in the proximal region and the autogenous tissue in the distal region.

In traumatic injuries, bone and soft tissue infections make cases quite challenging to cure. Especially in the first six hours after the trauma, adequate debridement increases the success rate of infection control $(6,7)$. Although elective revascularization was considered as the first option for the patient initially after the patient showed signs of critical ischemia, such as necrosis of the $5^{\text {th }}$ toe and rest pain, the patient had to undergo semiemergency revascularization while still showing clinical signs of infection.

In these circumstances, despite the risk of hematogenous infection at that moment, instead of the medial side of the left leg, the extraanatomical region of the lateral side of the femur is rather used as an operation field for the aim of local infection elimination and infected local tissue retraction.

The saphenous vein was passed through the interosseous membrane in that way medialized, and then the anastomosis of the saphenous vein to the posterior tibial artery was performed. In these types of injuries that are accompanied by soft tissue infection, despite intensive antibiotherapy, the risk of hematogenous transmitted graft infection is high even in the late period (8). The incidence of vascular graft infections ranges from $0.5 \%$ to $6 \%$ according to the location of the operational field. The most common microorganisms that can be isolated are Staphylococcus aureus and Staphylococcus epidermidis $(9,10)$. It should be kept in mind that sequential vascular grafting has more risk for infections as high as 15\% (11).

Some strategies can be applied to protect the anastomotic patency. The first of these is using antiplatelet and anticoagulation drugs. Another is to minimize the mobilization of the patient. Infection control also plays a critical role. In this case report, the patient mentioned was given low molecular weight heparin according to the patient's weight. Also, the mobilization of the patient was restricted and the infection was tried to be kept under control with dressing change twice a day and long-term intravenous antibiotic treatment. In addition, the patient was prescribed prophylactic oral antibiotherapy and $100 \mathrm{mg}$ acetylsalicylic acid per day at discharge.

\section{Conclusion}

To conclude, it should be kept in mind that we may face a number of postoperative complications that vary from bleeding to sudden death due to reperfusion injury. Considering all these difficulties and complications it is critical that the revascularisation process is performed by a technicallyequipped and experienced team. Finally, amputation should be kept in mind as the last treatment option in patients with lower extremity vascular damage and limb salvage should constitute the most basic step of treatment.

\section{Ethics}

Informed Consent: Informed consent was obtained from the patient.

Peer-reviewed: Externally peer-reviewed.

\section{Authorship Contributions}

Concept: A.Ö., Ö.A.Ç., i.Ş.B., H.K., I.A., Design: A.Ö., Ö.A.Ç., i.Ş.B., H.K., I.A., Data Collection or Processing: A.Ö., Ö.A.Ç., I.Ş.B., H.K., I.A., Analysis or Interpretation: A.Ö., Ö.A.Ç., I.Ş.B., H.K., I.A., Literature Search: A.Ö., Ö.A.Ç., I.S..B., H.K., I.A., Writing: A.Ö., Ö.A.Ç., i.S..B., H.K., i.A.

Conflict of Interest: No conflict of interest was declared by the authors.

Financial Disclosure: The authors declared that this study received no financial support.

\section{Kaynaklar}

1. Stranix JT, Anzai L, Mirrer J, et al. Dual venous outflow improves lower extremity trauma free flap reconstructions. J Surg Res. 2016;202:235-238.

2. Lang NW, Joestl JB, Platzer P. Characteristics and clinical outcome in patients after popliteal artery injury. J Vasc Surg. 2015;61:1495-1500.

3. Hafez HM, Woolgar J, Robbs JV. Lower extremity arterial injury: results of 550 cases and review of risk factors associated with limb loss. J Vasc Surg. 2001;33:1212-1219.

4. Langer V. Management of major limb injuries. Scientific World Journal. 2014;2014:640430.

5. Khan MI. ur Rahman H, Mufti N. Patency of Reverse Saphenous Vein Graft for Revascularization of Lower Limbs in Diabetic Patients. Int J Vasc Surg Med. 2016;2:20-23.

6. Elniel AR, Giannoudis PV. Open fractures of the lower extremity: Current management and clinical outcomes. EFORT Open Rev. 2018;3:316-325.

7. Werner CM, Pierpont Y, Pollak AN. The urgency of surgical débridement in the management of open fractures. J Am Acad Orthop Surg. 2008;16:369375.

8. Kilic A, Arnaoutakis DJ, Reifsnyder T, et al. Management of infected vascular grafts. Vasc Med. 2016;21:53-60.

9. Kysela P, Silhart Z. Vascular Graft Infection-A Single Centre Analysis. J Vasc Med Surg. 2015;1:1-6.

10. Murphy GJ, Pararajasingam R, Nasim A, et al. Methicillin-resistant Staphylococcus aureus infection in vascular surgical patients. Ann R Coll Surg Engl. 2001;83:158-163.

11. Ratliff CR, Strider D, Flohr T, et al. Vascular Graft Infection: Incidence and Potential Risk Factors. J Wound Ostomy Continence Nurs. 2017;44:524-527. 